\title{
Factors Explaining ICT Diffusion: Case Study of Selected Latin American Countries
}

\author{
Aziz Bakay, Collins E. Okafor, and Nacasius U. Ujah
}

\begin{abstract}
The eminent presence of globalization coupled with the advancement of information technology continues to penetrate and integrate societies and nations in a manner previously unknown. To stay competitive, most countries advocate and implement policies and amenities to encourage technological acceptance and adaptability. In this study, we investigate into the factors explaining the diffusion of ICT and its impact on economic activities. To gauge such, we examine the influence of ICT diffusion on a country's economic orientation. Our rationale is that greater the extent of ICT adoption in societies, the greater the economic and social development. For the purpose of this study, a set of Latin American countries is studied to capture the relative effect of various social, economical, and infrastructural variables into the overall ICT level, where ICT level is proxied by the Network Readiness Index adopted from World Economic Forum. The result indicates that a country's IT expenditure, age dependency ratio, literacy rate, and urbanization draw significant attention in explaining ICT diffusion in this region.
\end{abstract}

Index Terms-Age Dependency Ratio, Latin America Countries, Information Technology, ICT Readiness.

\section{INTRODUCTION}

A consensus among scholars and policy makers is that to understand the impact of globalization on world economies, as well as to gain an advantage in the opening of the competitive world that lowering of barriers would create, economies should not ignore the infusion effect of information technology and its diffusion within the immediate surroundings. While this phenomenon has increased trade, countries at present are relying on other strategies to attract more business and growth within their economies. Via regionalization, most countries that share similar traits often are compelled to rally around each other to attract the best of their community. Consequently, in this study we focus on the Latin American countries, henceforth LAC, to understand which indicators either increase or decrease ICT in these countries.

A selected number of LAC was chosen based on their gross domestic product per capita purchasing power parity. The rationale is high per capita countries are most likely to

Manuscript received April 10, 2010. Accepted August 30, 2010.

Aziz Bakay is with the Texas A\&M International University, Laredo, TX 78041 USA. (e-mail: azizbakay@dusty.tamiu.edu)

Collins E. Okafor is with the Texas A\& M International University, Laredo, TX 78041 USA. (e-mail: doncluminatti@dusty.tamiu.edu).

Nacasius U. Ujah is with the Texas A\& M International University, Laredo, TX 78041 USA. (nacasius.ujah@dusty.tamiu.edu) attract and spend more on information and communication technology, which also follows suit with findings by Chinn and Fairlie [10], Bagchi and Udo [4], etc. We differentiate our result by focusing on a particular region; all countries selected for this paper are developing or emerging countries to assert that possibly the degree to which these indicators play in these countries maybe different from previous findings, as argued by Bagchi and Edo [4]. The effects of these factors could be similar or different on developed and developing nations depending on the specific factor considered.

Furthermore, we find that the economic contributions of the statistically significant indicators used in this paper: Gross Domestic Product per capita on average, for every $\$ 3,333$ increase in the income per person in a country would lead to approximately 1 point increase in the Network Readiness score for the country.

In considering ICT, two terms are most prevalent: ICT Diffusion and Digital Divide (DD). Here, we distinctively bridge the gap between both concepts.

\section{A. ICT Diffusion}

In pursuit of growth and sustainability, countries continue to equip themselves with tools and resources to facilitate a clear-cut Information Communication Technology Diffusion. Diffusion here entails the implementation of essential measures that facilitate a country's network readiness (where readiness is considered on the basis of adaptability and efficiency of countries' productivity). Information and Communication Technologies (ICTs) are identified as network technologies [36] and key factors influencing economic growth [16] [26] [27] [36]. The sector of information and communication services is considered to be vital to the development processes of societies as long as it is competitive and vibrant in structure [38]. ICTs diffusion has been dynamic and variant across countries [27]. The diffusion is perceived important because ICT is substantially related to the electronic commerce in particular [28] and to the economic development at large [36]. The accurate usage of ICT in investment skills, organizational change and innovation leads to efficient and flourishing businesses [26].

ICTs continue to be an important factor in the development, effectiveness, and efficiency of both human and economic advancement. This is evident in the information sharing and network building that engulf most sectors (education, health, agriculture, financial markets etc.). Institutions and other business mediums continue to 
elevate towards more integrated and productive business environments [38].

\section{B. Digital Divide}

Digital divide (DD) is defined as the divergence of the ICTs worldwide and the disparity of digital opportunities within nation states and their dispersion among countries and territories (Digital Divide, n.d.). Despite the fact that DD has been bridged to some extent, there still exist inequalities across the world. As such, the challenge in this regard has been the process of diffusing and integrating ICTs within societies to garner the benefits of ICTs towards economic development [26].

Across countries, DD has been a persistent issue with reference to the speed and quality of access to ICTs. Nevertheless, the gap across countries and regions has been contracting [16] due to the increasing number of people having access to various communication devices and services.

Gurstein [14] elaborated on the differences between "access to ICTs" and "effectively use of ICTs". His argument is built upon the DD discussions on which recent summits, international meetings focus. However, according to him these meetings omitted aforementioned difference. Noticing that many applaud "having access" issues in terms of ICTs and pay attention to "haves" and "have nots" with respect to DD, he energizes the DD discussions by commenting on "effective use of ICTs". He defines it as follows: "the capacity and opportunity to successfully integrate ICTs into the accomplishment of self or collaboratively identified goals". Hence, the interaction of the society via ICT channels is levered by Gurstein's point. Therefore, the implementation of effectively using ICTs would create "benefit" that could be derived from the precondition of "having access" to ICTs. Enlarging the discussions to a broader understanding of the ICT usage in the essences of commerce, citizen participation, education, and government can form new ways of social development and growth.

The measures of ICTs include the number of mobile subscribers, main telephone lines, internet users, and fixed broadband subscribers. The mobile phone usage has been analyzed as the most evenly distributed ICT service device across countries of various income levels, whereas the fixed broadband subscribers were found to be the most unevenly distributed [17]. The International Telecommunication Union offers a snapshot for DD among countries. Each country is given a weighted score based on various ICT indicators highlighted above. Table 1 [16] captures the ten largest countries in Latin America based on their digital opportunity scores. The higher the score a country is assigned, the easier it is for citizens to gain access to ICT components. For Latin American countries, the highest score (0.57) is given to Chile, followed by Argentina, whereas Guatemala has the lowest score $(0.37)$ preceded by Ecuador and Peru (both 0.40). Considering the range of these scores (from highest 0.80 -Korea to lowest 0.03 -Niger), these selected countries fall fairly in the middle section. The average of these ten countries $(0.45)$ is slightly higher than the world average score $(0.40)$ and higher than the world median score (0.41-shared by Tunisia, Georgia, Panama, Ukraine, Egypt, Tonga).

TABLE I

DIGITAL OPPORTUNITY SCORES OF LARGEST TEN COUNTRIES IN LATIN AMERICA

\begin{tabular}{|c|c|}
\multicolumn{2}{|c|}{ LARGEST TEN COUNTRIES IN LATIN AMERICA } \\
\hline Chile & 0.57 \\
\hline Argentina & 0.51 \\
\hline Brazil & 0.48 \\
\hline Mexico & 0.47 \\
\hline Venezuela & 0.46 \\
\hline Colombia & 0.45 \\
\hline Dominican Republic & 0.42 \\
\hline Peru & 0.40 \\
\hline Ecuador & 0.40 \\
\hline Guatemala & 0.37 \\
\hline Average & 0.47 \\
\hline
\end{tabular}

Source: International Telecommunication Union (2007)

Perhaps asynchronously staged are the two concepts: digital diffusion and DD, where the former expresses the degree of concentration and spread of ICT while the later offers insight into the gap evident in countries regarding the circulation of ICTs. The two concepts refer to the same issue, which is digitalization of economies, but the terminology addresses the concept from two perspectives. Therefore, ICT diffusion relies on the spread of information about the existence of a new technology and learning from experience, as noted by Masfield [22]. Also, the greater the number of adopters, the greater the probability that other users will be contaminated, leading to the further spread of information and an accelerated diffusion speed [19].

\section{LITERATURE REVIEW}

The literature on DD and ICT measures can be classified into two streams of research: measuring DD across countries and explaining ICT measures [7]. On one hand, some studies focus on measuring and quantifying the DD, considering the evolution of the digital gap, in particular [25] [11] [3] [35]. The multi-dimensional character of the DD has led to elaborate ICT indexes to summarize information about the level of digitalization, such as the Information Society Index, the Networked Readiness Index, the Digital Access Index, the Digital Opportunity Index and the DD Index [33]. For instance, Corrocher and Ordanini [11] combine six different dimensions of digitalization in an index to obtain several patterns of digitalization in ten developed countries. Bagachi [3] creates an indicator including four different technologies, such as telephone (fixed and mobile), PC and Internet usage to measure and analyze the divide both globally and in different groups of 
countries. Vicente and Lo'pez use ten variables, [35] including PC, telephone lines, broadband connections, and secure servers to determine the DD among 15 European countries.

On the other hand, other empirical studies concentrate on explaining the determinants of ICT adoption and diffusion [15] [18] [6] [10]. Some researchers use cross-sectional data for a particular group of developed countries [15] [35], developing countries [30] [37] or both [6]. Several studies extend the analysis to consider cross-sectional time series for developing countries [31] [29] [13], while others include a combination of developing as well as developed countries.

In Table 2 we reference scholarly works that have some empirical findings related to our initial rationale for this paper.

\section{Methodology}

To measure the impact ICT diffusion in the selected countries in the Latin America region, we analyzed the ICT readiness levels on socio-economic indicators that might affect ICT diffusion either positively or negatively. These variables include unemployment rate, gross domestic product growth, GDP per capita, ICT Expenditure percentage of GDP, urbanization, Age Dependency Ratio, Gini index (income inequality), adult literacy rate, HDI (Human Development Index).

The variables tested are defined below in Table 3 .

TABLE II

BRIEF SUMMARIES OF EXTANT LITERATURE

\begin{tabular}{|c|c|}
\hline $\begin{array}{l}\text { Bagchi } \\
(2005)\end{array}$ & $\begin{array}{l}\text { Studied digital distance and its determinants in terms of } \\
\text { various indicators: economic, social, ethno-linguistic } \\
\text { and infrastructural factors }\end{array}$ \\
\hline $\begin{array}{l}\text { Becchetti and } \\
\text { Adriani } \\
(2005)\end{array}$ & $\begin{array}{l}\text { Empirical results indicates that the level and rate of } \\
\text { growth in income per worker predicatively explained } \\
\text { by the role of the ICT diffusion }\end{array}$ \\
\hline $\begin{array}{l}\text { Crenshaw \& } \\
\text { Robison } \\
(2006)\end{array}$ & $\begin{array}{l}\text { Examined the diffusion of internet usage in numerous } \\
\text { developing countries within the context of } \\
\text { globalization, integrating the cost of particular ICT } \\
\text { usage, education and the extent of liberalization of the } \\
\text { country }\end{array}$ \\
\hline $\begin{array}{l}\text { Kiiski \& } \\
\text { Pohjola } \\
(2002)\end{array}$ & $\begin{array}{l}\text { Affirms that GDP per capita and internet access cost } \\
\text { have been the significant explaining factors as opposed } \\
\text { to the previous studies that found the competition in } \\
\text { telecommunication as a significant explanatory variable }\end{array}$ \\
\hline $\begin{array}{l}\text { Udo et al. } \\
(2008)\end{array}$ & $\begin{array}{l}\text { Incorporated a qualitative approach covering four } \\
\text { developing countries in order to determine the } \\
\text { differences of ICT diffusion }\end{array}$ \\
\hline $\begin{array}{l}\text { Venkatesh } \\
\text { and Brown } \\
(2001)\end{array}$ & $\begin{array}{l}\text { Using a qualitative survey approach, investigated the } \\
\text { determinants of PC adoption by US households } \\
\text { whether it pertains to utilitarian, hedonic or social } \\
\text { outcomes. }\end{array}$ \\
\hline
\end{tabular}

\section{A. The Conceptual Model}

There are varying methods used to evaluate the factors that impact ICT diffusion, although very few have paid attention
TABLE III

DEFINITION OF VARIABLES

\begin{tabular}{|c|c|}
\hline $\begin{array}{l}\text { ICT Readiness } \\
\text { (Network Readiness } \\
\text { Index- NRI) }\end{array}$ & $\begin{array}{l}\text { Degree of preparation of a nation or } \\
\text { economy to participate in and benefit from } \\
\text { ICT developments. ICT readiness is proxied } \\
\text { by Network Readiness Index of World } \\
\text { Economic Forum. }\end{array}$ \\
\hline $\begin{array}{l}\text { Human Development } \\
\text { Index (HDI) }\end{array}$ & $\begin{array}{l}\text { A summary composite index that measures a } \\
\text { country's average achievements in three } \\
\text { basic aspects of human development: health, } \\
\text { knowledge, and a decent standard of living. } \\
\text { Health is measured by life expectancy at } \\
\text { birth; knowledge is measured by a } \\
\text { combination of the adult literacy rate and the } \\
\text { combined primary, secondary, and tertiary } \\
\text { gross enrolment ratio; and standard of living } \\
\text { by GDP per capita (PPP US\$). }\end{array}$ \\
\hline $\begin{array}{l}\text { GDP per capita } \\
\text { (GDP) }\end{array}$ & $\begin{array}{l}\text { A country's productivity in terms of the } \\
\text { value of goods and services produced per } \\
\text { person. It is computed by dividing the overall } \\
\text { GDP by the country's population. It can also } \\
\text { be related to productivity and efficiency. }\end{array}$ \\
\hline $\begin{array}{l}\text { Annual GDP Growth rate } \\
\text { (AGDP) }\end{array}$ & $\begin{array}{l}\text { Annual growth rate is the annual percentage } \\
\text { change in the total annual output of a } \\
\text { country's economy in constant prices. GDP is } \\
\text { the total market value of all final goods and } \\
\text { services produced in a country in a given } \\
\text { year, equal to total consumer, investment, } \\
\text { and government spending. }\end{array}$ \\
\hline $\begin{array}{l}\text { Age Dependency Ratio } \\
\text { (\% of Working-Age } \\
\text { Population) }\end{array}$ & $\begin{array}{l}\text { Age dependency ratio is the ratio of } \\
\text { dependents--people younger than } 15 \text { or older } \\
\text { than } 64 \text {--to the working-age population-- } \\
\text { those ages } 15-64 \text {. Data are shown as the } \\
\text { proportion of dependents per } 100 \text { working- } \\
\text { age population }\end{array}$ \\
\hline $\begin{array}{l}\text { ICT Expenditure percentage } \\
\text { of GDP } \\
\text { (ICT_EXP) }\end{array}$ & $\begin{array}{l}\text { Information and communications technology } \\
\text { expenditures include computer hardware, } \\
\text { computer software, computer services, and } \\
\text { communications services, and wired and } \\
\text { wireless communications equipment. }\end{array}$ \\
\hline $\begin{array}{l}\text { Adult Literacy Rate } \\
\text { (ALR) }\end{array}$ & $\begin{array}{l}\text { Derived from HDI; comprises of adult } \\
\text { literacy rates and the combined gross } \\
\text { enrolment ratio for primary, secondary and } \\
\text { tertiary schooling, weighted to give adult } \\
\text { literacy more significance in the statistic. }\end{array}$ \\
\hline $\begin{array}{l}\text { Gini Index } \\
\text { (GINI) }\end{array}$ & $\begin{array}{l}\text { Measures the degree of income inequality in } \\
\text { a society or country. The level of income } \\
\text { inequality addresses the issue of fair or } \\
\text { uneven income distribution in a given } \\
\text { country or society. }\end{array}$ \\
\hline $\begin{array}{l}\text { Urbanization } \\
\text { (URB) }\end{array}$ & $\begin{array}{l}\text { A process in which people migrate from } \\
\text { smaller village or towns to bigger cities and } \\
\text { suburbs in search of greener pastures. This } \\
\text { process can be connected to industrialization. } \\
\text { As a country gets more industrialized, more } \\
\text { jobs and other opportunities are created for } \\
\text { its citizens. }\end{array}$ \\
\hline $\begin{array}{l}\text { Unemployment } \\
\text { (UNRATE) }\end{array}$ & $\begin{array}{l}\text { The percentage of those in the labor force } \\
\text { who are unemployed helps measure a } \\
\text { country's economic position at a particular } \\
\text { stage of study. This economic position } \\
\text { includes insufficient effective demand for } \\
\text { goods and services in the economy, thereby } \\
\text { creating unemployment as firms and } \\
\text { organizations result to downsizing. }\end{array}$ \\
\hline
\end{tabular}

Source: World Econiomic Forum (WEF) \& World Development Indicator (WDI) 
to the diffusion of ICT in developing nations, like Udo et al [4]. Although Udo et al [4] focused on qualitative analysis to show nation-specific impact, for the purpose of this study we have chosen to use regression models to quantitatively show to what extent these variables are related to ICT diffusion in the selected Latin American countries. Other authors have focused more on developed societies. For instance, Dedrick et al [39] used nation-specific analysis to investigate the factors accounting for the divergence of ICT diffusion in nine developed countries. They concluded that various factors, like economic development, education system, infrastructures, investment in ICT, and government policies, resulted in the differences in ICT diffusion. EinDor et al [40] found that unique factors like government policies of countries were attributed to degrees of ICT diffusion.

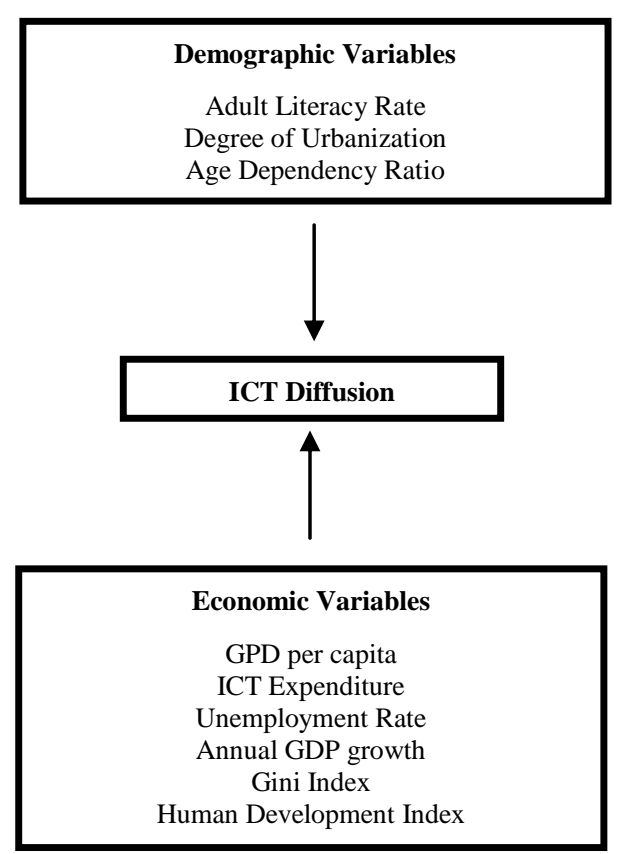

Fig. 1. Conceptual Model

In our study we pay attention to the raising impact of regionalization, looking at the factors that impact ICT diffusion in Latin American countries. In this paper we selected the ten biggest earning countries based on their gross domestic product. All the factors selected have been considered in previous research to impact ICT diffusion, however, to what extent they are prevalent in developing countries is the primary focus of our study. As such, Figure 1 below is our conceptual model outlining our dependent and independent variables derived from the earlier studies in this subject.

Our variables, which are categorized into demographic and economic variables, impact the readiness and diffusion of ICT in each of these countries. The ICT Readiness, which is used as our dependent variable, is proxied by Network Readiness Index. This index is pulled from the Global Information Technology Report, a World Economic Forum publication. The scores given to countries in this index underline the level of technological readiness and innovation that are essential engines towards growth needed in countries to prevail over economic crisis as well as position themselves for sustainability.

\section{B. Analytic Model}

In this study, we use specific information from Latin American countries extracted from various international non-governmental agencies like the United Nations Development Program, World Development Indicators from World Bank Group, and Global Technology Report from the World Economic Forum. The purpose, here, is to regress and test these variables and analyze the magnitudes of their impact on NRI. The Latin American countries used in this study are Mexico, Brazil, Argentina, Colombia, Venezuela Chile, Peru, Dominican Republic, Guatemala, and Ecuador.

Prior to regressing these variables on the ICT readiness scores, we ran a correlation matrix to confirm that these variables were actually not excessively correlated with our dependent variable. The table 4 demonstrates the correlation matrix; there is an exceptionally high correlation coefficient (0.920) between urbanization and adult literacy rates and their individual Variance Inflation Factor (VIF) mean scores were high as well. Therefore, in order to address this issue, we created an artificial variable consisting of these two variables so that we could hinder bias of multicollinearity in our linear models. We named this new variable as ALR_URB. Our reasoning of this particular variable creation is as follows: In most of the developing countries in Latin America, the proportion of literate people in the urban areas is higher compared to the proportion of literate people in rural areas. Hence the higher the urban force and literacy level, the more ICT Diffusion would take place. Thus, we conclude that these two variables are measuring highly similar component of the countries, which creates the need for eliminating one of the variable or merging both variables. The technique as stipulated above is derived from the concept of VIF.

Across the correlation table, we see that GDP per capita as measured with the purchasing power parity does have the highest positive correlation with NRI (Network Readiness Index), HDI (Human Development Index), URB (Urbanization) and, ALR (Adult Literacy Rate), yet their correlations are not considered prohibitively high. Hence, we regress all, although we were cautious because some of the variables maybe highlighted correlated with each other.

Our present study uses longitudinal (2004 - 2008) data for these countries. In running the test, we assume that: Not all variables would impact ICT readiness in the aforementioned countries, which led us to create four models. Thus we could test and observe to what extent these variables have impact on ICT diffusion.

The possibility of a lag effect exists in which a dependant variable is correlated with values of the independent (delayed) variable. Scholars that have used this method include [21] and [9]. Although their studies were not based 
TABLE IV

CORRELATION MATRIX

\begin{tabular}{|l|l|l|l|l|l|}
\hline & ICT_R & HDI & GDP & AGDP & AGEDEP \\
\hline ICT_R & 1.000 & & & & \\
\hline HDI & 0.153 & 1.000 & & & \\
\hline GDP & 0.423 & 0.850 & 1.000 & & \\
\hline AGDP & -0.212 & 0.128 & -0.119 & 1.000 & \\
\hline AGEDEP & -0.461 & -0.271 & -0.585 & 0.027 & 1.000 \\
\hline ICT_EXP & 0.148 & 0.188 & -0.056 & -0.120 & 0.291 \\
\hline ALR & 0.108 & 0.649 & 0.629 & 0.348 & -0.733 \\
\hline GINI & -0.023 & -0.603 & -0.621 & -0.255 & 0.174 \\
\hline URB & 0.083 & 0.701 & 0.642 & 0.475 & -0.557 \\
\hline UNRATE & -0.131 & -0.158 & -0.265 & 0.456 & -0.140 \\
\hline & IT_EXP & ALR & GINI & URB & UNRATE \\
\hline ICT_EXP & 1.000 & & & & \\
\hline ALR & -0.013 & 1.000 & & & \\
\hline GINI & 0.404 & -0.388 & 1.000 & & \\
\hline URB & -0.033 & 0.920 & -0.598 & 1.000 & \\
\hline UNRATE & 0.298 & 0.366 & 0.356 & 0.363 & 1.000 \\
\hline
\end{tabular}

on ICT topics, we utilize their approach to reduce the effect of multicollinearity as well as endogeneity.

As such, we decided to test our four regression models (given below) in three stages. First, we analyzed a situation in which there is no lag on the right-hand side as well as left hand-side variables. Second, we take into consideration a one year lag effect, and third, we take into consideration a two year lag effect.

In all our results, we must check for the presence of variance inflation factor and test for robustness. Consequently, the linear regression models used to regress the disparity and diffusion of ICT among Latin American countries are as follows:

Model 1:

ICT_R ${ }_{i}=\beta_{0}+\beta_{1} \mathrm{GDP}_{i}+\beta_{2} \mathrm{ICT}_{-} \mathrm{EXP}_{i}+\beta_{3} \mathrm{ALR}_{-} \mathrm{URB}_{i}$

Model 2:

ICT_R $R_{i}=\beta_{0}+\beta_{1} \mathrm{GDP}_{i}+\beta_{2}$ ICT_EXP $+\beta_{3}$ ALR_URB +

$\beta_{4} \operatorname{AGEDEP}_{i}$

Model 3:

ICT_R ${ }_{i}=\beta_{0}+\beta_{1} \mathrm{GDP}_{i}+\beta_{2} \mathrm{ICT}_{-} \mathrm{EXP}_{i}+\beta_{3} \mathrm{ALR}_{-} \mathrm{URB}_{i}+$

$\beta_{4} \operatorname{AGEDEP}_{i}+\beta_{5}$ UNRATE $_{i}$

Model 4:

ICT_R $R_{i}=\beta_{0}+\beta_{1} \mathrm{GDP}_{i}+\beta_{2} \mathrm{ICT}_{-} \mathrm{EXP}_{i}+\beta_{3} \mathrm{ALR}_{-} \mathrm{URB}_{i}+$

$\beta_{4} \operatorname{AGEDEP}_{i}+\beta_{5} \mathrm{UNRATE}_{i}+\beta_{6} \mathrm{AGDP}_{i}+\beta_{7} \mathrm{GINI}_{i}$

Where;

ICT_R $R_{i}$ : Information and Communication

Technologies Readiness in country $i$.

GDP : GPD per capita.

ICT_EXP: ICT Expenditure percentage of GDP.

ALR : Adult Literacy Rate.

URB : Urbanization.

ALR_URB : Artificial variable combination of Adult

Literacy Rate and Urbanization.

AGEDEP: Age Dependency Ratio.
UNRATE : Unemployment rate.

AGDP : Annual GDP growth rate.

GINI : GINI index.

HDI : Human Development Index.

\section{RESULTS}

Initially three stages of regressions were performed: a no lag, a one-year lag, and a two-year lag. We found that no lag and one-year lag regressions signaled higher power in the sense of statistical and economic significance of the variables as opposed to two-year lag models. We later, eliminate the two year lag effect from our regression results. We reveal our regression model (OLS) results for each model considering the presence of lag effects at a one year and a no-lag effect on the variables. Below is Table 5, which illustrates the descriptive statistics of variables included in our study.

TABLE V

DESCRIPTIVE STATISTICS

\begin{tabular}{|l|l|l|l|l|}
\hline & Mean & Std. Dev. & Min & Max \\
\hline ICT_R & 1.86 & 2.07 & -1.08 & 3.91 \\
\hline HDI & 0.82 & 0.026 & 0.79 & 0.86 \\
\hline GDP & 9707.84 & 2770.67 & 5806.61 & 14495.3 \\
\hline AGDP & 6.80 & 3.29 & 1.77 & 18.28 \\
\hline AGEDEP & 57.64 & 2.52 & 53.62 & 63.18 \\
\hline ICT_EXP & 4.42 & 0.84 & 3.43 & 6.14 \\
\hline ALR & 91.63 & 4.46 & 84.19 & 97.64 \\
\hline GINI & 51.73 & 4.49 & 43.44 & 58.66 \\
\hline URB & 78.32 & 10.63 & 62.94 & 93.32 \\
\hline UNRATE & 9.37 & 3.49 & 3.16 & 15.02 \\
\hline
\end{tabular}

To analyze the data, we perform an Ordinary Least Squares (OLS) regression analysis. OLS generates estimates for unknown parameters by minimizing sum of squared residuals (distances between the observed values of the independent variables and predicted values from linear approximation). The regression coefficients give us a better insight into variables' impact on ICT Readiness. All regression results are robust (to reduce the effect of outliers and variations), standardized, and constantly checked for high multicollinearity (to reduce the pressure of correlation among variables).

We have utilized STATA software for this regression. The results took into effect missing variables; thereby reducing our data size from fifty (50) to thirty (30) observations. To control for the multicollinearity, we tested our variables with the Variance Inflation Factor (VIF). This command generates VIF scores for every variable that ranges from 1.00 to infinity, as well as a mean VIF score. A VIF score higher than 10.0 is recognized as an indication of multicollinearity that could hamper the purpose of the analysis. In our various models, the mean VIF scores are less than 2.5 , an acceptable level of multicollinearity. 
Our regression results are shown in Table $6 a$ and $6 \mathrm{~b}$. In both no lag and one-year lag regressions, GDP per capita has been found to be significant in 4 out of 8 models, and the variable has positive sign in 6 out of 8 models given below (Table $6 \mathrm{a}$ and $6 \mathrm{~b}$ ). Software produced positive coefficient for Annual GDP Growth having no statistical significance. GINI index had negative coefficients in both regressions having no statistical significance. Unemployment rate had positive coefficient in 3 out of 4 models below. Although its direction confirms with the intuitive interpretation of the model, none of them is statistically significant.

Results suggest that socio-economic variables like, expenditure on ICT (ICT_EXP) and Age Dependency Ratio (AGEDEP) of the selected Latin American countries, do impact ICT. Both indicators are statistically significant and their coefficients are attributed vital impact. An increase in Age Dependency Ratio (coefficients range from - 0.5557 to 1.0354) consequently showed a negative impact on ICT Readiness in the selected LACs. All coefficients of Age Dependency Ratio are highly significant ( $1 \%$ level). In oneyear lag regression, coefficient for this variable in model 4 is (-0.7326). Therefore, an increase in ICT expenditure (coefficients range from 0.4272 to 1.8184 ) positively impacted the ICT Readiness in the selected LACs. In oneyear lag regression, coefficient for this variable in model 4 is (1.3007) and it is significant under $1 \%$ level. The combination of adult literacy and urbanization (ALR_URB) manifests level of significance (5 out of 8 models). In model 4 of the one-year lag regression, software generated (0.2308) as the coefficient of ALR_URB signifying a negative association compared to slightly larger coefficient of the same variable $(-0.4479)$ in model 4 of the no lag regression.

Considering the overall explanatory power of the models, R-squared scores are 0.6366 and .6084 in no lag and oneyear lag regressions respectively. As the additional variables are included in the models R-squared scores improve.

To further strengthen this paper, we decided to run a stepwise regression. Although this method is mostly used on the onset of knowing which variable would impact a dependant indicator, we decided to use it at the confirmatory stage. Thus, it will serve to reaffirm that the indicators tested above were actually impacting the left-hand side variable. The two stages were also applied; hence, we generated a table for easy comparison of all regression results as shown in table 6 .

Table $6 \mathrm{a}$ and $6 \mathrm{~b}$ show results considering the No-Lag Effect, One Year Lag, Two Year Lag. Below are results of the Stepwise Regression (Table 7). This method included the HDI index in addition to the aforementioned variables that are attributed statistical significance in the no lag model. Hence our regression model changed from the initial to the table below.

The stepwise regression created similar outputs compared to the previous models: Larger coefficients for ICT_EXP,
TABLE VIA

NO LAG REGISTRATION RESULTS

(DEPENDANT VARIABLE IS ICT READINESS INDEX)

\begin{tabular}{|l|l|l|l|l|}
\hline & Model 1 & Model 2 & Model 3 & Model 4 \\
\hline GDP & $0.0005 * * *$ & $0.0003 *$ & 0.0003 & 0.0003 \\
\hline ICT_EXP & 0.4272 & $0.8649 * *$ & $0.8461 *$ & $1.8184 * *$ \\
\hline ALR_URB & -0.0887 & $-0.1685 * * *$ & $-0.1734 *$ & $-0.4479 * * *$ \\
\hline AGEDEP & & $-0.5609 * * *$ & $-0.5557 * * *$ & $-1.0354 * *$ \\
\hline UNRATE & & & 0.0129 & 0.1488 \\
\hline AGDP & & & & 0.2452 \\
\hline GINI & & & & -0.3162 \\
\hline & & & & \\
\hline N & 30 & 30 & 30 & 30 \\
\hline Constant & 2.8727 & $41.5392 * * *$ & $41.4705 * * *$ & $101.5646 * * *$ \\
\hline R-Squared & 0.2668 & 0.4959 & 0.4960 & 0.6366 \\
\hline
\end{tabular}

Significance levels: $1 \%(* * *), 5 \%(* *), 10 \%(*)$.

negative but larger coefficients of AGEDEP, positive coefficient of Annual GDP Growth.

TABLE VIB

ONE YEAR LAG REGRESSION RESULTS

(DEPENDANT VARIABLE IS ICT READINESS INDEX)

\begin{tabular}{|c|c|c|c|c|}
\hline & Model 1 & Model 2 & Model 3 & Model 4 \\
\hline GDP & $0.0004 * * *$ & $0.0003^{*}$ & 0.0000 & 0.0000 \\
\hline ICT_EXP & $0.6210^{*}$ & $0.8661 * *$ & $1.0642 * *$ & $1.3007 * * *$ \\
\hline ALR_URB & -0.0690 & $-0.1494 * *$ & -0.0642 & $-0.2308 *$ \\
\hline AGEDEP & & $-0.5505^{* * *}$ & $-0.5795 * * *$ & $-0.7326^{* * *}$ \\
\hline UNRATE & & & -0.1766 & 0.0100 \\
\hline AGDP & & & & 0.0627 \\
\hline GINI & & & & -0.2083 \\
\hline $\mathrm{N}$ & 30 & 30 & 30 & 30 \\
\hline Constant & 0.8652 & $40.2880 * * *$ & $38.2972 * * *$ & $68.1663 * * *$ \\
\hline R-Squared & 0.3032 & 0.5221 & 0.5456 & 0.6084 \\
\hline
\end{tabular}

Significance levels: $1 \%(* * *), 5 \%(* *), 10 \%(*)$.

GDP per capita, combination of adult literacy rate and urbanization, and GINI index have never found to be as much contributive in our models, hence they were not assigned any coefficient. Human Development Index has a positive and significant ( $1 \%$ level) coefficient. The R-

TABLE VII

STEPWISE REGRESSION RESULTS

(No LAG, ONE YEAR LAG AND Two YeARs LAG ModeLS)

\begin{tabular}{|l|l|l|}
\hline & No Lag & One Yr Lag \\
\hline GDP & & \\
\hline ICT_EXP & $1.4604 * * *$ & $1.2623 * * *$ \\
\hline ALR & $-1.0417^{* * *}$ & $-0.7442^{* * *}$ \\
\hline URB & $0.1391 * *$ & $0.1898^{* * *}$ \\
\hline ALR_URB & & \\
\hline AGEDEP & $-1.4458^{* * *}$ & $-1.010^{* * *}$ \\
\hline UNRATE & & $-0.1400^{* *}$ \\
\hline AGDP & $0.1813^{*}$ & \\
\hline GINI & & \\
\hline HDI & $38.9992^{* * *}$ & \\
\hline & & \\
\hline Constant & $129.9856^{* * *}$ & $110.0959 * * *$ \\
\hline R-Squared & 0.7303 & 0.7123 \\
\hline
\end{tabular}

Significance levels: $1 \%(* * *), 5 \%(* *), 10 \%(*)$

squared of the stepwise regressions are higher than 0.5 in both models. Therefore, all of the coefficients are significant at least $10 \%$ level which is the principle of stepwise regression that we utilized. 
Excluding the stepwise regression model, we see that the presence of lag-effect does not really exist when regressing for ICT Diffusion in Latin American Countries. This result could be due to the following reason; literacy rate, urbanization, and Age Dependency Ratio are not influenced by diffusion, ICT could be an enhancer to these variables. However, we can state finitely that ICT Expenditure (has a positive correlation coefficient) and the Age Dependency Ratio (has a negative correlation coefficient) does have strong correlation in explaining the level of ICT Diffusion in the selected Latin American Countries.

\section{IMPLICATIONS}

Using ICT Readiness Index scores as a proxy for ICT Diffusion, we align policy implication from the statistically significant variables in Table $6 \mathrm{~b}$ model 4. Although the output of Table 6 a results are more linear compared to Table $6 \mathrm{~b}$ when considering the R-square, we feel that socioeconomic indicators captured in this paper as proposed by scholars like Bagchi [3] and Becchetti and Adriani [5] their effect would proceed to ICT Diffusion. For instance, IT Expenditure in the selected Latin American countries would aide towards the diffusion of ICT among its citizens, as such the economic substance of the statistical significant variables are enumerated from Table $6 \mathrm{~b}$.

From both Tables $6 \mathrm{a}$ and $6 \mathrm{~b}$, we find that IT expenditure and age dependency ratio are statistically significant. Following economic substance deduction as suggested by [23], we make our posit from Table $6 \mathrm{~b}$ that an increase in one standard deviation of ICT Expenditure and Age Dependency Ratio in these selected Latin American countries would impact ICT Diffusion in these countries by $0.5874 \%$ and $-0.9926 \%$ respectively. These numbers in table 8 were generated by applying the following computation adopted from [23].

$[($ Coefficient* STD $) /$ Mean $]=$ Economic Significance

TABLE VIII

ECONOMIC SIGNIFICANCE

\begin{tabular}{|l|c|c|c|}
\multicolumn{4}{|c}{ ECONOMIC SIGNIFICANCE } \\
\begin{tabular}{|c|c|c|} 
Coefficient \\
$($ ICT_EXP)
\end{tabular} & $\begin{array}{c}\text { STD } \\
(\text { ICT_EXP) }\end{array}$ & $\begin{array}{c}\text { Mean } \\
(\text { ICT_R })\end{array}$ & $\begin{array}{c}\text { Economic } \\
\text { Significance }(\%)\end{array}$ \\
\hline 1.3007 & 0.84 & 1.86 & 0.587412903 \\
\hline-0.7326 & 2.52 & 1.86 & -0.992554839 \\
\hline
\end{tabular}

Therefore, in précis we suggest that these countries should increase their investment in ICT, and economically create jobs that would reduce the gap of the dependency ratio to their working population.

In Table 5, we find that the average unemployment rate of the ten selected Latin American Countries is 9.37. We can also conclude that an increase in ICT diffusion would positively impact the countries by creating jobs either via ICT investment or other industrial channels; this would in turn lead to a substantial improvement in Age Dependency Ratio. While this paper does give an overall perspective to the economic situations within these economies, we cannot categorically infer which sector or industry each country should further explore. Also, the amplitude for investing in ICT cannot specifically address what types of ICT procurement and service should these countries undertake. As such, further research in this area would need to be undertaken.

\section{LIMITATIONS AND FUTURE RESEARCH}

A sample size of ten countries in Latin America was used in this research. These countries were chosen in terms of their GDP and populations size. The selected countries might not have been a good representation of Latin America as a whole, which might be viewed as a limitation or constraint.

The data collection process was hampered by the unavailability of data for certain periods. This might have slightly thrown off the absolute validity of the data in terms of the variable computation. Some countries had missing data for some of the years being studied. Even though, based on our analysis, the missing data do not pose a significant treat to the overall result, awareness of this constriction is vital for future research.

The time periods observed for the purpose of this research are 2002-2008. For future research, an extended period would probably yield a more grounded result. For example, unforeseen events like natural disasters, terrorism and other economical and political events might significantly swerve the behavioral dynamics of a country's stability. If so, such events should be evaluated and accounted for when compiling and deciding which countries would better represent an entire region.

Also, perhaps it may be best to perform a country analysis on the variables as one considers all Latin American Countries. Focusing on each country at a time would clearly indicate which variable(s) do affect the Diffusion of ICT in these countries.

For the purpose of this study, we contained our research within the boundaries of Latin America; a comparison of different geographic regions would also be an interesting idea for future research. This would expand the criteria for ICT infusion determinant, as differences in culture and governmental policies would greatly differ when addressing vastly divergent societies. Another idea would be to use countries that share similar economic traits like developing, emerging and developed countries. The combination of countries from these economic classifications might result in an association disparity.

\section{DISCUSSION AND CONCLUSION}

This paper examines the threads of association between the levels of ICT in countries with analytical insights into the economic, social and demographic frameworks. Researchers and Scholars have concluded that ICT level is a function of economic development and infrastructure of a country, as well as a driver for competitiveness. The 
macroeconomic variables that we have operationalized in this study have helped in explaining the ICT phenomenon in Latin American countries. In most of the regression analysis, GDP per capita and IT expenditure divided by GDP are found to be significant in explaining the variance in the ICT scores of countries. These results are supporting the extant literatures like [3] [2] [7] implying the importance of GPD per capita.

Although our statistical significant findings are in line with the above mentioned scholars, we go further to discuss the economic contribution of significant variables. In this paper, we find that for every $\$ 3,333$ increase in the income per person in a country, it would lead to approximately a one point increase in the Network Readiness score of the country. Also, all things being equal, the expenditure on information technology as it relates to GDP or any other variable should be increased. An increase in expenditure would impact ICT Diffusion in Latin American Countries by an average of forty-eight percent, allowing infrastructural improvements and enhancing both individual and business usage of ICT goods and services across the country.

The degree of Age Dependency Ratio (a social factor) is another significant variable posit a negative association with ICT level. The rationale behind this is based on the following argument: The younger the labor force, the more association and assimilation with connection and communication through ICT, thus, the increase of network, which could translate to more social interaction. Therefore, the individual and business usage of mobile phone, PC, internet, etc. increases as the level of Age Dependency Ratio decreases. As mentioned in the methodology section of this paper, the construct "a" was generated to control for the multicollinearity between urbanization and literacy variables. Therefore, in most of the regression analyses 'a' construct was found to capture the significant portion of the dependent variable variance. We have concluded that the country having more urbanization and literacy creates more access to and opportunities of ICT for its citizens.

\section{ACKNOWLEDGMENT}

The authors would like to thank four anonymous reviewers for their critique and suggestions.

\section{REFERENCES}

[1] Asfaw, M., \& Korrapati, R. (2006). Information and Communication Technologies with Ethopia: Sociopersonal Factors Affecting Adaptation and Use. Allied Academies International Conference. Academy of Information and Management Sciences. Proceedings, 10(2), 21-27.

[2] Bagchi, K., Hart, P. \& Peterson, M. F. (2004). National Culture and Information Technology Product Adoption. Journal of Global Information Technology Management, 7(4), 29-46.

[3] Bagchi, K. (2005). Factors Contributing to Global Digital Divide: Some Empirical Results. Journal of Global Information Technology Management, 8(3), 47-65.

[4] Bagchi, K. \& Udo, G. (2007). Empirically Testing Factors that Drive ICT Adoption in Africa and OECD Set of Nations. Issues in Information Systems, 8(2), 45-52.
[5] Becchetti, L. \& Adriani, F. (2005). Does the Digital Divide Matter? The Role of Information and Communication Technology in Crosscountry Level and Growth Estimates. Economics of Innovation \& New Technology, 14(6), 435-453.

[6] Beilock, R., \& Dimitrova, D. V. (2003). An exploratory model of inter-country Internet diffusion. Telecommunications Policy, 27(3-4), 237-252.

[7] Billon, M; Marco, R; \& Lera-Lopez, F. (2009). Disparities in ICT Adoption: A Multidimensional Approach to Study the Cross-country Digital Divide. Telecommunication Policy, 33(10), 596-610.

[8] The Digital Divide (n.d.) The Digital Divide. Retrieved March 31, 2010 from Bridge the Digital Divide website: http://www.bridgethedigitaldivide.com/digital_divide.htm

[9] Caetano, Jose; and Caleiro, Antonio. (2009). Is there a Relationship between Transparency in Economic and Political Systems and Foreign Direct Investment Flows? ICFAI Journal of Applied Economics, 8(2), $45-58$.

[10] Chinn, M. D., \& Fairlie, R. W. (2007). The Determinants of the Global Digital Divide: A Cross-Country Analysis of Computer and Internet Penetration. Oxford Economic Papers, 59(1), 16-44.

[11] Corrocher, N., \& Ordanini, A. (2002). Measuring the digital divide: A framework for the analysis of cross-country differences. Journal of Information Technology, 17(1), 9-19.

[12] Crenshaw, E. M. \& Robison, K. K. (2006). Globalization and the Digital Divide: The Roles of Structural Conduciveness and Global Connection in Internet Diffusion. Social Science Quarterly, 87(1), 190-207.

[13] Dasgupta, S., Lall, S., \& Wheeler, D. (2005). Policy reform, economic growth and the digital divide. Oxford Development Studies, 33(2), 229-243.

[14] Gurstein, M. (2003). Effective Use: A Community Informatics Strategy beyond the Digital Divide. First Monday, 8(12). Retrieved from: http://firstmonday.org/htbin/cgiwrap/bin/ojs/index.php/fm/article/vie $\underline{\mathrm{w} / 1107 / 1027}$

[15] Hargittai, E. (1999). Weaving the Western Web: Explaining differences in Internet connectivity among OECD countries. Telecommunications Policy, 23(10-11), 701-718.

[16] ITU (International Telecommunication Union) \& UNCTAD. World Information Society Report 2007: Beyond WSIS. Geneva: ITU, 2007.

[17] ITU. Report on World Summit on Information Society Stocktaking. Geneva: ITU, 2008.

[18] Kiiski, S. \& Pohjola, M. (2002). Cross-country Diffusion of the Internet. Information Economics and Policy, 14(2), 297-310.

[19] Karshenas, M., \& Stoneman, P. (1995). Technological diffusion. In P. Stoneman (Ed.), Handbook of the economics of innovation and technological change (pp. 265-297). Oxford: Blackwell.

[20] Kiiski, S., \& Pohjola, M. (2002). Cross-country diffusion of the Internet. Information Economics and Policy, 14(2), 297-310.

[21] Lo, A. W., and MacKinlay, A. C. (1990). When are Contrarian Profits due to Stock Market Overreaction? Review of Financial Studies, 3(2), $175-205$

[22] Mansfield, E. (1968). Industrial Research and Technological Innovation. New York: Norton.

[23] Miller, J. E. \& Rodgers, Y. Van der M. (2008). Economic Importance and Statistical Significance: Guidelines for Communicating Empirical Research. Feminist Economics, 14(2), 117 - 149.

[24] Mutula, M.S., and Brakel, P.V. (2007). ICT Skills Readiness for the Emerging Global Digital Economy among the SMEs in Developing Economies: Case study of Botswana. Library Hi Tech, 25(2): 231245.

[25] OECD. Working party on indicators for the information society. DSTI/ICCP/IIS4. Paris: OECD, 2005.

[26] OECD. The Economic Impact of ICT: Measurement, Evidence and Implications. Paris: OECD, 2004.

[27] OECD. ICT and Economic Growth: Evidence from OECD Countries, Industries and Firms. Paris: OECD, 2003.

[28] OECD. The Economic and Social Impact of Electronic Commerce: Preliminary Findings and Research Agenda. Paris: OECD, 1999. 
[29] Oyelaran-Oyeyinka, B., \& Lal, K. (2005). Internet diffusion in subSaharan Africa: A cross-country analysis. Telecommunications Policy, 29(7), 507-527.

[30] Quibria, M. G., Shamsun, A. N., Tschanh, T., \& Reyes-Macasaquit, M. (2003). Digital divide: Determinants and policies with special reference to Asia. Journal of Asian Economics, 13(6), 811- 825.

[31] Tanner, E. (2003). Bridging Latin America's digital divide: Government policies and Internet access. Journalism Mass Communication Quarterly, 80(3), 646-665.

[32] Udo, G.; Bagchi, K. K. \& Kirs, P. J. (2008). Diffusion of ICT in Developing Countries: A Qualitative Differential Analysis. Journal of Global Information Technology Management, 11(1), 6-27.

[33] Vehovar, V., Sicherl, P., Hu“sing, T., \& Dolnicar, V. (2006). Methodological challenges of digital divide measurement. The Information Society, 22(5), 279-290.

[34] Venkatesh, V. \& Brown, S. A. (2001). A Longitudinal Investigation of Personal Computers in Homes: Adoption Determinants and Emerging Challenges. MIS Quarterly, 25(1), 71-102.

[35] Vicente, M. R., \& Lo'pez, A. J. (2006). A multivariate framework for the analysis of the digital divide: Evidence for the European Union15. Information and Management, 43(6), 756-766.

[36] WEF (World Economic Forum). The Global Information Technology Report 2008-2009. Geneva: WEF, 2009.

[37] Wong, P. K. (2002). ICT production and diffusion in Asia: Digital dividends or digital divide? Information Economics and Policy, 14(2), 167-187.

[38] World Bank. Information Technologies and Development, Geneva: World Bank, 2007.

[39] Dedrick, J.L.; Goodman, S.E. \& Kraemer, K.L. (1995). Little Engines that could: Computing in Small Energetic Countries. Communications of ACM, 38(5), 21-26.

[40] Ein-Dor, P.; Myers, M.D. \& Raman, K.S. (1997). Information Technology in Three Small Developed Countries. Journal of Management Information Systems, 13(4), 61-89. 